Sains Malaysiana 49(3)(2020): 683-691

http://dx.doi.org/10.17576/jsm-2020-4903-23

\title{
Kajian terhadap Tanah Liat Bentonit dan Kaolin sebagai Perisai Sinaran
}

(Study on Clay Bentonite and Kaoline as Shielding Material)

\author{
Nur FATIN NABILAH ZUHAIRI, NORSYAHIDAH MOHD HIDZIR*, AZUHAR RipIN, MOHD IDZAT IDRIS \& \\ NUR AIN MOHD RADZALI
}

\begin{abstract}
ABSTRAK
Plumbum (Pb) merupakan perisai sinaran yang utama bagi mengurangkan dedahan sinaran gama. Pb mempunyai bilangan atom dan ketumpatan yang tinggi. Walau bagaimanapun, Pb adalah bersifat toksik, sangat berat serta mempunyai tahap penyerapan neutron yang sangat rendah. Justeru, perisai sinaran dengan ciri-ciri yang ideal seperti ringan dan berkeupayaan tinggi dalam menghalang sinaran sedang giat diterokai. Antara perisai yang sedang dikaji pada masa kini ialah yang diperbuat daripada tanah liat. Tanah liat mempunyai ciri-ciri takat lebur yang tinggi, kestabilan termokimia dan kekuatan mekanik pada suhu yang tinggi. Ciri-ciri ini menjadikan tanah liat berpotensi sebagai perisai sinaran. Justeru, kajian ini dijalankan bagi menentukan perincian unsur, nilai pekali pengecilan serta perbandingan nilai ketebalan kesetaraan plumbum untuk tanah liat (iaitu bentonit dan kaolin). Perincian unsur tanah liat ditentukan daripada analisis pembelauan sinar-X (XRD) dan mikroskop imbasan medan elektron (FESEM). Ujian pembakaran tanah liat dilakukan pada suhu $\sim 1000{ }^{\circ} \mathrm{C}$ bagi melihat sebarang perubahan terhadap sifat fizikal dan kimia tanah liat. Sementara itu, ujian bagi penentuan pekali pengecilan dilakukan menggunakan sumber sinaran gama dan sinar-X. Hasil analisis menunjukkan tiada perubahan yang ketara bagi sifat kimia dan fizikal tanah liat selepas ujian pembakaran. Berdasarkan pekali pengecilan, tanah liat jenis bentonit mempunyai nilai pekali pengecilan yang lebih tinggi berbanding kaolin dengan hampir 90\% pengurangan dos berjaya diperoleh. Akhir sekali, analisis ketebalan kesetaraan plumbum menunjukkan nilai kesetaraan bagi bentonit adalah tinggi berbanding kaolin. Kesimpulannya, tanah liat bentonit menunjukkan keupayaan pengurangan dos yang tinggi untuk digunakan sebagai perisai sinaran.
\end{abstract}

Kata kunci: Bentonit; kaolin; perisai sinaran; tanah liat; sinar-X

\section{ABSTRACT}

Lead $(\mathrm{Pb})$ is a main shielding material for gamma radiation. Lead has a high number of atoms and density. However, lead is toxic, very heavy and has low neutron absorption capacity. Therefore, a shielding material with ideal characteristics such as lightweight and high radiation attenuation are actively being explored. Among the shielding material that currently being studied are those made of clay. Clay has high melting point, thermochemical stability and high mechanical strength. These features make the clay potentially be used as a shielding material. Therefore, this study was carried out to determine the element presence in the clay, the attenuation coefficient and the comparison of leadequivalent thickness values for clay (i.e. bentonite and kaoline). The details of the clay elements were determined by using X-ray diffraction (XRD) analysis and field emission scanning electron microscopy (FESEM). Clay combustion tests were conducted at $\sim 1000^{\circ} \mathrm{C}$ in order to see any changes in the physical and chemical properties. Meanwhile, the test for the determination of the attenuation coefficient was performed using a source of gamma and X-ray. The results showed that no significant changes in the chemical and physical properties of the clay after the combustion test. Based on the attenuation coefficient, bentonite has a higher attenuation coefficient compared to kaoline with almost $90 \%$ of dose reduction achieved. Finally, lead equilibrium thickness analysis showed that bentonite's equilibrium value was higher than kaoline. In conclusion, bentonite shows high reduction of dose capability to be used as a radiation shielding.

Keywords: Bentonite; clays; kaoline; shielding; X-rays

\section{PENGENALAN}

Secara amnya, terdapat tiga prinsip asas perlindungan sinaran iaitu masa, jarak dan perisai. Bagi melindungi dan mengurangkan impak sinaran terhadap individu, penggunaan masa atau tempoh yang singkat ketika mengendalikan bahan radioaktif perlu dipraktikkan. Selain itu, jarak diri dengan bahan radioaktif juga memainkan peranan iaitu semakin jauh jarak diri terhadap bahan radioaktif, semakin kecil dedahan yang diterima. Akhir sekali, perisai merupakan teknik yang terbaik bagi melindungi diri daripada terdedah kepada sinaran yang berbahaya.

Jenis perisai sinaran yang diperlukan bergantung kepada jenis sinaran yang digunakan. Terdapat tiga jenis sumber sinaran yang utama iaitu zarah alfa, beta dan sinaran gama. Zarah alfa mempunyai jisim yang besar sehingga tidak boleh bergerak jauh di udara, namun mempunyai kuasa penembusan yang sangat rendah. Zarah 
alfa boleh dihalang dengan sehelai kertas. Manakala zarah beta boleh bergerak dengan mudah di udara dan mempunyai kuasa penembusan yang tinggi berbanding zarah alfa. Unsur yang mempunyai bilangan atom yang rendah seperti aluminium digunakan untuk menghalang zarah beta. Sinaran gama mempunyai kuasa penembusan yang tinggi dan dapat menembusi badan manusia dengan mudah. Oleh itu, bahan berketumpatan tinggi digunakan sebagai perisai sinaran gama, contohnya, plumbum.

Plumbum kerap digunakan sebagai bahan perisai sinaran kerana mempunyai bilangan atom yang tinggi, berketumpatan tinggi, serta perlindungan yang berkesan terhadap sinaran gama. Menurut kajian oleh Singh et al. (2004), kaca yang mempunyai komposisi plumbum mampu memerisai sinaran gama dengan ciri-cirinya lebih baik berbanding konkrit. Selain itu, dalam kajian oleh Erdem et al. (2010), sisa pepejal logam yang mempunyai komposisi plumbum juga mampu menghalang sinaran gama dan boleh digunakan sebagai bahan bagi pembinaan bangunan. Walau bagaimanapun, plumbum dikenali dengan ketoksikan, sementara baju perisai seperti apron yang digunakan di hospital-hospital bagi melindungi pekerja daripada sinaran adalah sangat berat (Yusuf et al. 2010). Selain itu, kos penghasilan bagi satu blok plumbum adalah tinggi. Justeru, bahan-bahan yang lebih berkesan untuk menggantikan plumbum sebagai perisai sinaran sedang giat diterokai.

Tanah liat merupakan bahan semula jadi yang terdiri daripada mineral galian halus. Menurut Tilki et al. (2017), tanah liat seperti bentonit dan kaolin diguna secara meluas dalam proses pemangkinan, bahan penjerap radionuklid dan penyimpanan bahan sisa nuklear. Tanah liat mempunyai ciri-ciri takat lebur yang tinggi, kestabilan termokimia, kekuatan mekanik pada suhu yang tinggi, rintangan kejutan terma yang tinggi dan penyusutan haba yang rendah, serta mempunyai rintangan yang tinggi terhadap kakisan (Folorunso et al. 2014). Ciri-ciri ini menjadikan tanah liat sesuai atau berpotensi untuk dijadikan bahan perisai sinaran. Dalam kajian oleh Ripin et al. (2019), seramik mullite barite yang terdiri daripada kaolin dan barite didapati sesuai digunakan sebagai perisai perlindungan sinaran terutamanya pada kemudahan perubatan sinar-X kerana mempunyai integriti pemerisaian sinaran yang tinggi. Dalam kajian tersebut, ketebalan kesetaraaan plumbum adalah hampir sama iaitu dalam julat $0.25-0.37$ $\mathrm{mm}$.Pb sebelum dan selepas proses pembakaran (maksimum suhu $1100{ }^{\circ} \mathrm{C}$ ), menunjukkan ketahanan terhadap haba yang tinggi. Kajian oleh Olukotun et al. (2018) yang menggunakan tanah liat jenis kaolin dan bebola tanah liat daripada Nigeria menyimpulkan bahawa ia mampu dijadikan sebagai perisai sinaran dalam bidang perubatan mahupun nuklear. Dalam kajian tersebut, pekali pengecilan didapati berkadar secara songsang dengan tenaga sinaran gama, iaitu semakin tinggi tenaga, semakin rendah pekali pengecilan. Kajian lain daripada Mann et al. (2016), mendapati tanah liat dengan komposisi batu bata daripada jenis abu terbang memberi manfaat dalam menghalang sinaran gama, namun ketebalan yang tinggi adalah perlu jika dibandingkan dengan konkrit.
Justeru, kajian ini dilakukan bagi mencapai tiga objektif, iaitu menentukan perincian unsur dan nilai pekali pengecilan bagi tanah liat (bentonit dan kaolin), serta membandingkan nilai ketebalan kesetaraan plumbum terhadap tanah liat tersebut.

\section{BAHAN DAN KAEDAH KAJIAN}

Serbuk kaolin (100\%) dan bentonit (100\%) diperoleh daripada syarikat Concord Chemicals dan sumber sinaran gama iaitu Amerisium-241 (Am-241) bertenaga $59 \mathrm{keV}$ diperoleh daripada Agensi Nuklear Malaysia (ANM).

\section{PENYEDiaAn SAMPEl TANAH LiaT}

Tanah liat bentonit dan kaolin dimasukkan ke dalam piring petri masing-masing dan dikeringkan menggunakan ketuhar elektrik pada suhu $150{ }^{\circ} \mathrm{C}$ selama 24 jam (Ripin et al. 2018) bagi menyahkelembapan yang terdapat pada kedua-dua sampel. Kemudian sampel dikisarkan menggunakan ball mill pada kelajuan $300 \mathrm{rpm}$ selama 30 minit bagi menjadikan sampel sebati. Setelah itu, sampel mengalami proses mampatan iaitu sampel dimasukkan ke dalam acuan yang disediakan bagi menghasilkan sampel tanah liat berbentuk cakera iaitu berdiameter $4 \mathrm{~cm}$ dengan ketebalan yang berlainan (iaitu 3, 5 serta $10 \mathrm{~mm}$ tebal). Bagi setiap ketebalan, 3 replikasi sampel dihasilkan. Berat dan tekanan yang dikenakan pada setiap sampel bergantung kepada ketebalan sampel. Sebahagian daripada sampel tanah liat seterusnya dijadikan dalam bentuk seramik tanah liat dengan pembakaran menggunakan relau elektrik Nabertherm iaitu pada suhu $900{ }^{\circ} \mathrm{C}$ untuk sampel bentonit dan $1000{ }^{\circ} \mathrm{C}$ bagi sampel kaolin. Sampel seterusnya dibiarkan pada suhu pembakaran tersebut selama 120 minit sebelum relau dimatikan semalaman (Ripin et al. 2018). Sampel yang telah siap mengalami proses pembakaran disimpan dalam bekas penyimpan. Dalam kajian ini, sampel tanah liat ditanda dengan $\mathrm{K}(\mathrm{a})^{\mathrm{c}}$ dan $\mathrm{B}(\mathrm{a})^{\mathrm{c}}$ dengan $\mathrm{K}$ mewakili kaolin, B untuk bentonit, a mewakili ketebalan sampel, dan c mewakili proses pembakaran. Contohnya, $\mathrm{K}(3)^{\mathrm{c}}$ mewakili sampel kaolin dengan ketebalan $3 \mathrm{~mm}$ yang telah dibakar.

\section{UJIAN PERINCIAN BENTONIT DAN KAOLIN}

Perincian unsur ke atas sampel bentonit dan kaolin dijalankan di Pusat Pengurusan Penyelidikan dan Instrumentasi (CRIM), UKM dengan penggunaan mesin pembelauan sinar-X (XRD) (Bruker D8 Advance) dan mesin mikroskop imbasan medan elektron (FESEM) (ZEIS S GeminiSEM (500)). Sampel dibahagi kepada dua bahagian iaitu tanah liat asal dan tanah liat yang mengalami proses pembakaran (sampel seramik). Untuk ujian XRD, sampel dimasukkan ke dalam bekas petri dan diratakan. Kemudian, sampel dimasukkan ke dalam mesin pembelauan sinar-X. Sampel disinar pada sudut pembelauan $10^{\circ}-80^{\circ}$ dengan panjang gelombang, $\lambda 1.5406 \AA$ Á. Bagi menganalisis spektrum setiap sampel, perisian diffrac eva digunakan. Sifat morfologi sampel tanah liat dan seramik tanah liat 
bagi sebelum dan selepas pembakaran dikaji dengan menggunakan FESEM pada tenaga keupayaan $15 \mathrm{kV}$. Magnifikasi yang digunakan ketika kajian ini adalah 10 $\mathrm{kx}-30 \mathrm{kx}$

\section{LENGKUNGAN KALIBRASI PLUMBUM}

Dalam kajian ini, lengkungan kalibrasi plumbum diperoleh dengan menggunakan dua sumber sinar yang berbeza iaitu sinaran gama (Am-241 dengan tenaga $59 \mathrm{keV})$ dan sinar-X (60 - $120 \mathrm{kV})$. Penentuan nilai ketebalan kesetaraan plumbum terhadap sampel bentonit dan kaolin dilakukan dengan meletakkan kepingan plumbum di antara sumber sinaran dan pengesan sinaran (UNFORS Xi BASE UNIT 179527). Bagi Am-241, kepingan plumbum berketebalan $0.1 \mathrm{~mm}$ hingga $1.5 \mathrm{~mm}$ telah digunakan. Manakala untuk sinar-X, kepingan plumbum berketebalan $0.1 \mathrm{~mm}$ hingga $0.6 \mathrm{~mm}$ digunakan.

\section{UJIAN PEKALI PENGECILAN, $\mu$}

Susunan radas bagi ujian pekali pengecilan $(\mu)$ adalah sama seperti dalam Hopkins et al. (2012). $\mu$ ditentukan berdasarkan (1):-

$$
\mu=-\frac{\frac{\ln I}{\ln I_{0}}}{\chi}
$$

dengan $\mathrm{I}_{\mathrm{o}}$ dan I ialah keamatan awal dan akhir sinaran dan $\chi$ ialah ketebalan sampel.

Berdasarkan nilai $\mu$, peratusan pengurangan dos bagi sampel bentonit dan kaolin dapat ditentukan menggunakan (2):-

$$
\% \text { Pengurangan dos }=\left(1-\frac{\mathrm{I}}{\mathrm{I}_{\mathrm{o}}}\right) \times 100 \%
$$

\section{Keputusan dan Perbincangan}

\section{ANALISIS PERINCIAN UNSUR BAGI BENTONIT DAN KAOLIN}

Hasil ujian XRD (Rajah 1(a) dan 1(b)) mendapati puncak yang terhasil pada spektrum sampel bentonit selepas proses pembakaran berada pada fasa amorfus. Fasa amorfus ini adalah selari dengan kajian oleh Ekosse dan MulabaBafibiandi (2008). Dalam kajian ini, hasil XRD menunjukkan bentonit terdiri daripada mineral yang dominan iaitu montmorillonit dan kuartza (Jadual 1). Sistem kristal bagi mineral montmorillonit adalah monoklinik manakala kuartza adalah heksagon. Merujuk kepada Jadual 1, peratusan mineral montmorillonit menurun sebanyak $5 \%$ bagi sampel $\mathrm{B}(3)^{\mathrm{c}}$ berbanding bentonit asal (55\%). Sebaliknya terdapat peningkatan pada peratusan mineral kuartza selepas proses pembakaran iaitu meningkat sebanyak 5\%. Mineral montmorillonit mendominasi sampel bentonit berbanding mineral lain seperti yang pernah dilaporkan oleh Naswir et al. 2013 dan Toshifumi et al. 2010.

Sampel tanah liat kaolin pula mengandungi dua mineral utama iaitu kaolinit dan kuartza (Jadual 1). Mineral kaolinit hadir dalam kaolin dengan peratusan yang tinggi iaitu 99\% dengan sistem kristal triklinik (Rajah 1(c) dan 1(d) dan Jadual 1). Manakala kandungan mineral kuartza bagi sampel ini sangat rendah iaitu $0.87 \%$ dengan kristalnya adalah heksagon. Hasil analisis tidak menunjukkan perubahan ketara selepas proses pembakaran (peratusan mineral dalam sampel K(3) adalah hampir sama dengan seramik $\left.\mathrm{K}(3)^{\mathrm{c}}\right)$. Hasil XRD dalam kajian ini adalah sama seperti yang telah dilaporkan oleh Kłosek-Wawrzyn et al. (2013) dengan kehadiran mineral seperti kaolinit dan kuartza.

\section{ANALISIS MORFOLOGI BENTONIT DAN KAOLIN}

Rajah 2(a), menunjukkan morfologi sampel bentonit B(3) yang hadir tanpa bentuk yang seragam. Agregat platelet (ditunjukkan dengan anak panah) terhasil pada Rajah 2(b) yang dibentuk oleh lapisan montmorillonit yang dipengaruhi dengan suhu pembakaran. Hasil kajian ini adalah sama dengan kajian oleh Górniak et al. (2016). Rajah 2(c) menunjukkan mineral kaolinit yang dominan tersusun rapi. Berdasarkan kajian oleh Saeed et al. (2013), tanah liat kaolin mempunyai struktur agregat yang tersusun kemas dan struktur berbuku. Saiz butiran antara sampel kaolin $\mathrm{K}(3)$ dan seramik kaolin $\mathrm{K}(3)^{\mathrm{c}}$ adalah sedikit berbeza dengan saiz butiran seramik kaolin $\mathrm{K}(3)$ c (Rajah 2(d)) adalah hampir dua kali ganda lebih besar berbanding dengan sampel kaolin yang asal pada Rajah 2(c).

JADUAL 1. Peratusan mineral pada bentonit dan kaolin sebelum dan selepas pembakaran

\begin{tabular}{lccccc}
\hline Sampel & Jenis tanah liat & Proses pembakaran $\left({ }^{\circ} \mathrm{C}\right)$ & \multicolumn{3}{c}{ Peratusan mineral (\%) } \\
& & & Montmorillonit & Kuartza & Kaolinit \\
\hline $\mathrm{B}(3)$ & Bentonit & 0 & 55.67 & 44.33 & 0 \\
$\mathrm{~B}(3) \mathrm{c}$ & Bentonit & 900 & 50.26 & 49.74 & 0 \\
$\mathrm{~K}(3)$ & Kaolin & 0 & 0 & 0.87 & 99.13 \\
$\mathrm{~K}(3) \mathrm{c}$ & Kaolin & 1000 & 0 & 1.05 & 98.95 \\
$\mathrm{~K}(3) \mathrm{c}$ & Kaolin & 1000 & 0 & 1.05 & 98.95 \\
\hline
\end{tabular}



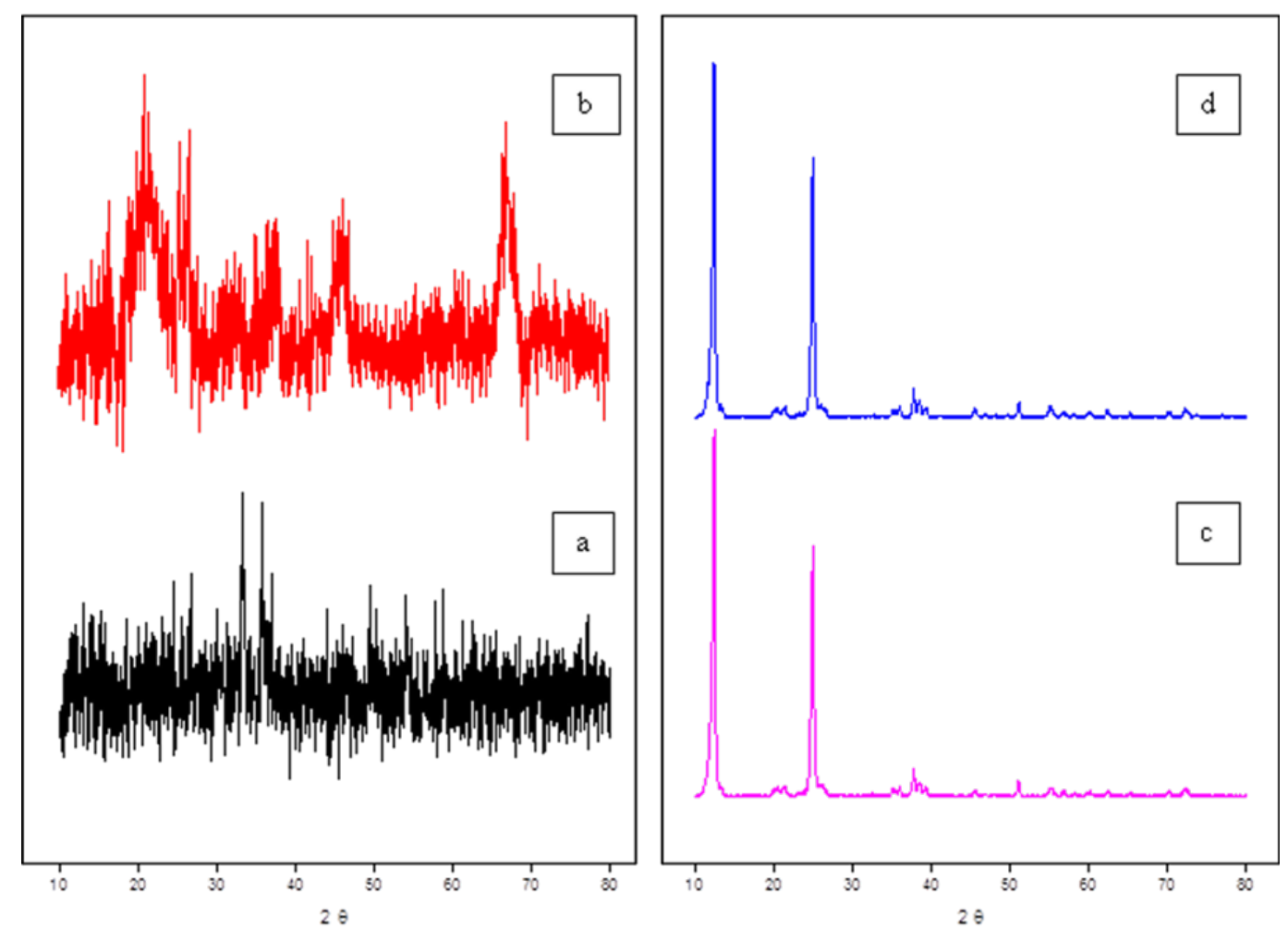

RAJAH 1. Spektrum XRD bagi (a) sampel asal bentonit B(3), (b) sampel seramik bentonit B(3)c, (c) sampel asal kaolin K(3), dan (d) sampel seramik kaolin K(3)c
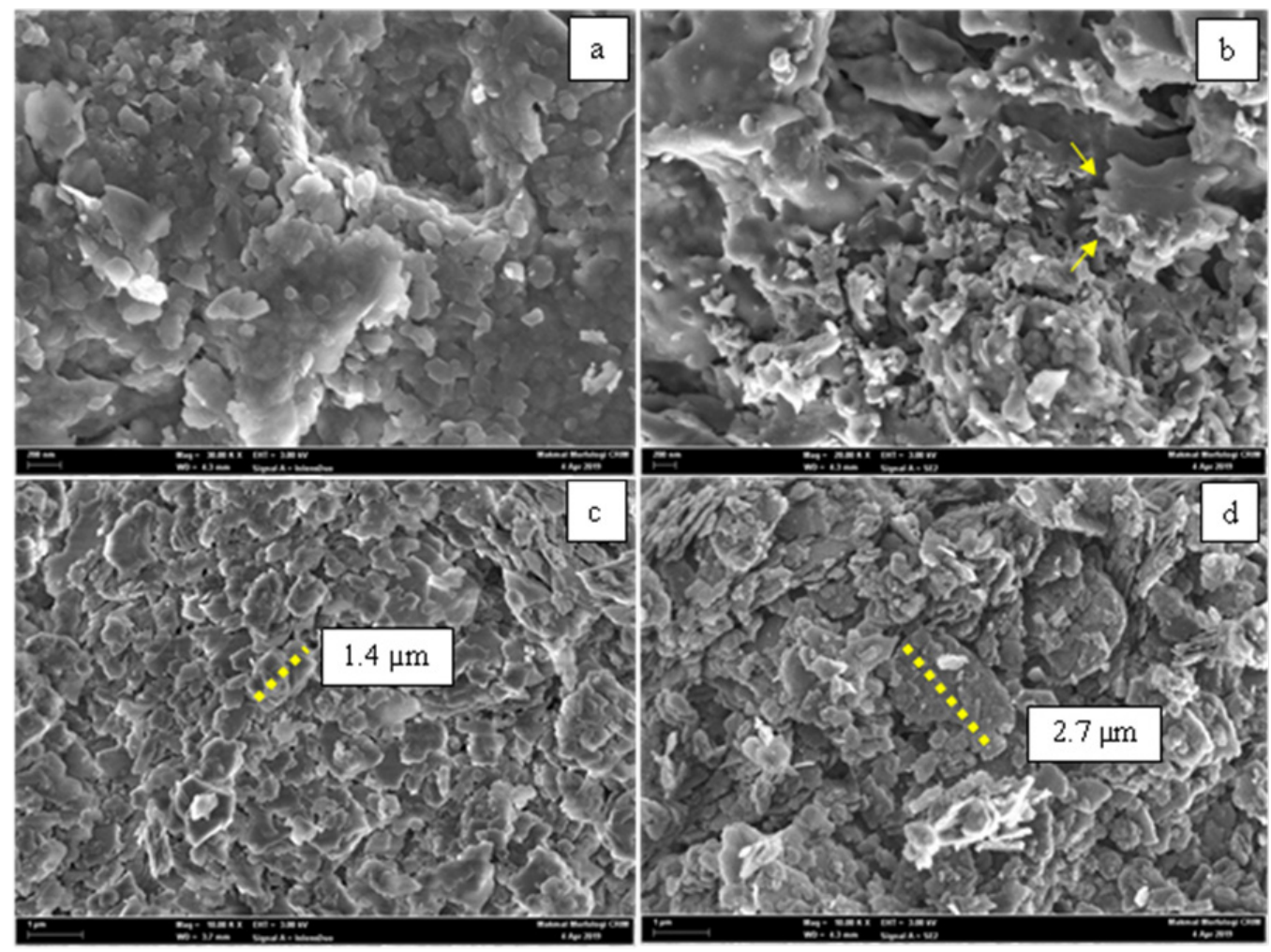

RAJAH 2. Analisis FESEM bagi (a) sampel asal bentonit B(3) [magnifikasi 30kx], (b) sampel seramik bentonit, B(3)c [magnifikasi $20 \mathrm{kx}$ ], (c) sampel asal kaolin K(3) dan (d) sampel seramik kaolin, K(3)c [magnifikasi 10kx] 


\section{PEKALI PENGECILAN BENTONIT DAN KAOLIN}

Nilai pekali pengecilan $(\mu)$ bagi sumber sinaran gama (Am-241) berdasarkan (1) bagi kedua-dua sampel bentonit dan seramik bentonit adalah hampir sama iaitu masingmasing $0.005 \mathrm{~cm}^{-1}$ dan $0.006 \mathrm{~cm}^{-1}$. Sementara nilai $\mu$ sinaran gama ialah $0.004 \mathrm{~cm}^{-1}$ diperoleh bagi sampel kaolin dan seramik kaolin. Rajah 3 menunjukkan keamatan (ln I/ $\mathrm{I}_{\mathrm{o}}$ ) berkadar secara langsung dengan ketebalan sampel bentonit dan kaolin. Hasil kajian ini adalah selari dengan kajian oleh Hopkins et al. (2012). Menurut Hopkins et al. (2012) ketebalan sampel aloi MCP-96 berkadar langsung dengan nilai $\ln$ (I/Io) kerana dalam kajian tersebut, semakin meningkat ketebalan sampel, nilai ln (I/Io) semakin meningkat tetapi dipengaruhi dengan tenaga sumber yang digunakan. Data menunjukkan sampel seramik dengan ketebalan $10 \mathrm{~mm}$ berjaya mengurangkan keamatan sinaran dengan lebih berkesan berbanding sampel seramik berketebalan $3 \mathrm{~mm}$.

Jadual 2 menunjukkan nilai $\mu$ yang diperoleh daripada kedua-dua sampel bentonit dan kaolin bagi sumber sinar-X (julat $60-120 \mathrm{kV}$ ). Nilai $\mu$ yang paling tinggi bagi sampel bentonit adalah $0.017 \mathrm{~cm}^{-1}$ pada nilai keupayaan mesin sinar-X yang rendah iaitu $60 \mathrm{kV}$. Manakala nilai $\mu$ sebanyak $0.010 \mathrm{~cm}^{-1}$ diperoleh pada nilai keupayaan 120 $\mathrm{kV}$ mesin sinar-X bagi sampel bentonit. Berdasarkan jadual tersebut, nilai $\mu$ bagi sampel bentonit adalah tinggi berbanding dengan sampel kaolin pada semua tenaga keupayaan. Nilai $\mu$ semakin berkurangan apabila tenaga keupayaan mesin sinar-X bertambah.

Kajian oleh Olukotun et al. (2018) menunjukkan tanah liat kaolin dan bebola tanah liat mengalami proses pembakaran mempunyai nilai $\mu$ pada julat $0.097-0.098$ $\mathrm{cm}^{-1}$ pada tenaga $1764.49 \mathrm{keV}$, manakala pada tenaga $609.31 \mathrm{keV}$, julat nilai $\mu$ adalah $0.160-0.163 \mathrm{~cm}^{-1}$. Keputusan kajian oleh Olukotun et al. (2018) adalah sama dengan kajian ini dengan nilai $\mu$ adalah berbeza dan bergantung kepada tenaga sinaran yang dikenakan.

\section{LENGKUNGAN KALIBRASI PLUMBUM DAN PERBANDINGAN KETEBALAN KESETARAAN PLUMBUM}

Nilai sinaran gama tanpa sebarang kepingan plumbum direkodkan sebanyak $3300 \mu \mathrm{R} / \mathrm{hr}$. Walau bagaimanapun, nilai sinaran gama menurun secara signifikan menjadi $0.008 \mu \mathrm{R} / \mathrm{hr}$ apabila ketebalan kepingan plumbum meningkat kepada $1.5 \mathrm{~mm}$. Julat nilai ketebalan kesetaraan plumbum bagi sampel bentonit berketebalan 3, 5 dan 10 mm apabila disinarkan dengan sinar gama adalah $0.04 \pm$ $0.02 \mathrm{~mm} . \mathrm{Pb}$ hingga $0.1 \pm 0.01 \mathrm{~mm} . \mathrm{Pb}$ (Jadual 3). Manakala nilai ketebalan kesetaraan plumbum bagi sampel kaolin apabila disinarkan dengan sinar gama adalah pada julat $0.035 \pm 0.01 \mathrm{~mm}$. Pb hingga $0.078 \pm 0.01 \mathrm{~mm} . \mathrm{Pb}$. Secara keseluruhannya, nilai kesetaraan plumbum bagi sampel bentonit adalah hampir 10\% lebih tinggi berbanding dengan sampel kaolin.

Manakala, bagi sinar-X tanpa sebarang perisai sinaran direkodkan $10446 \mu \mathrm{Gy}$. Walau bagaimanapun, bacaan sinar-X menurun menjadi $311 \mu \mathrm{Gy}$ apabila ketebalan plumbum meningkat kepada $0.6 \mathrm{~mm}$. Berdasarkan Jadual 3 , ketebalan sampel kaolin dan bentonit didapati berkadar secara langsung terhadap nilai kesetaraan plumbum. Menurut Kementerian Kesihatan Malaysia (KKM), ketebalan minimum $2 \mathrm{~mm} . \mathrm{Pb}$ diperlukan bagi operasi yang melibatkan sinar-X (KKM 2017). Justeru, dalam kajian ini, sampel bentonit memerlukan ketebalan sebanyak $\sim 100$ mm untuk setara dengan $2.0 \mathrm{~mm}$.Pb yang telah ditetapkan oleh KKM. Dalam kajian ini, nilai ketebalan kesetaraan plumbum bagi sampel seramik bentonit adalah pada julat $0.04-0.12 \mathrm{~mm} . \mathrm{Pb}$, iaitu lebih tinggi berbanding sampel kaolin iaitu 0.02 - 0.062 mm.Pb. Berdasarkan Jadual 3,

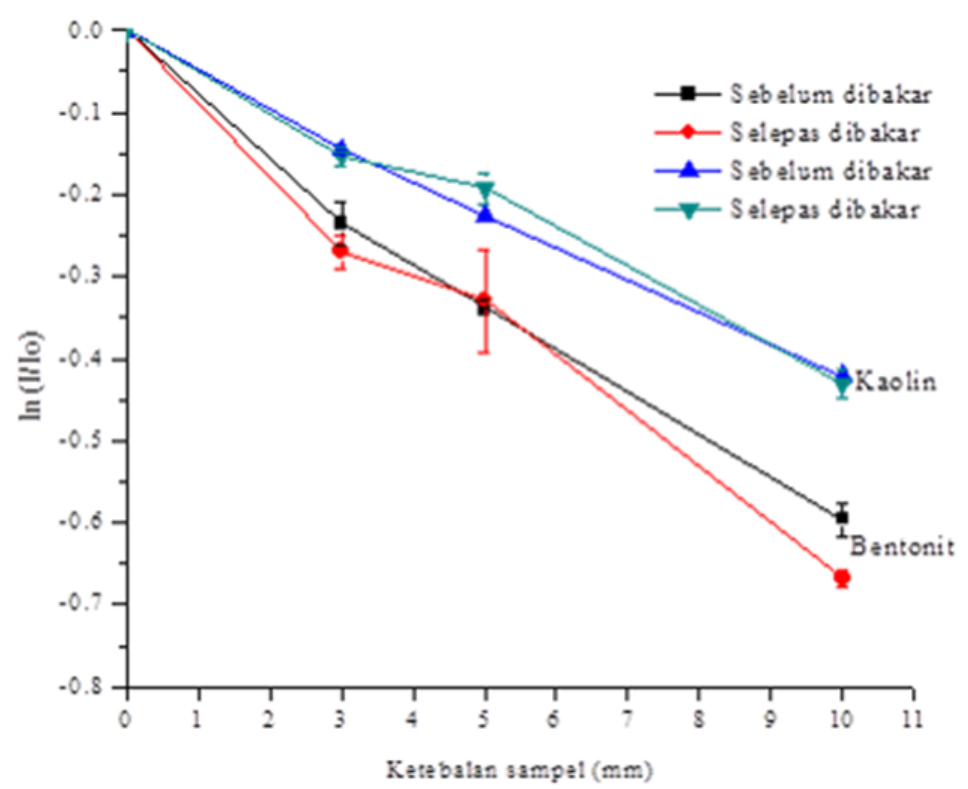

RAJAH 3. Keamatan In (I/Io) melawan ketebalan sampel bentonit dan kaolin 
JADUAL 2. Nilai pekali pengecilan, $\mu$ bagi sampel bentonit dan kaolin pada tenaga keupayaan mesin sinar-X yang berlainan

\begin{tabular}{lccccc}
\hline Jenis tanah liat & $\begin{array}{c}\text { Proses pembakaran } \\
\left({ }^{\circ} \mathrm{C}\right)\end{array}$ & 60 & \multicolumn{3}{c}{ Tenaga keupayaan mesin sinar-X $(\mathrm{kV})$} \\
& 0 & 0.017 & 0.014 & 100 & 0.013 \\
\hline Bentonit & 900 & 0.016 & 0.014 & 0.012 & 0.010 \\
Bentonit & 0 & 0.011 & 0.009 & 0.007 & 0.010 \\
Kaolin & 1000 & 0.011 & 0.008 & 0.007 & 0.006 \\
Kaolin & & & & \\
\hline
\end{tabular}

JADUAL 3. Ketebalan kesetaraan plumbum antara bentonit dan kaolin

\begin{tabular}{lccccccc}
\hline Sumber sinaran & Proses pembakaran & \multicolumn{3}{c}{ Ketebalan bentonit $(\mathrm{mm})$} & \multicolumn{3}{c}{ Ketebalan kaolin (mm) } \\
& & 3 & 5 & 10 & 3 & 5 & 10 \\
\cline { 2 - 7 } & & & \multicolumn{5}{c}{ Ketebalan Kesetaraan Plumbum (mm) } \\
\hline Am-241 (59 keV) & Tidak & 0.040 & 0.050 & 0.100 & 0.035 & 0.040 & 0.078 \\
& Ada & 0.040 & 0.050 & 0.100 & 0.035 & 0.040 & 0.078 \\
Sinar-X (kV) & & & & & & & \\
60 & Tidak & 0.048 & 0.058 & 0.100 & 0.020 & 0.030 & 0.050 \\
& Ada & 0.050 & 0.060 & 0.100 & 0.020 & 0.030 & 0.055 \\
80 & Tidak & 0.044 & 0.060 & 0.100 & 0.020 & 0.037 & 0.058 \\
& Ada & 0.050 & 0.060 & 0.110 & 0.020 & 0.038 & 0.059 \\
100 & Tidak & 0.039 & 0.062 & 0.120 & 0.021 & 0.039 & 0.060 \\
& Ada & 0.040 & 0.062 & 0.120 & 0.030 & 0.038 & 0.060 \\
& Tidak & 0.042 & 0.060 & 0.110 & 0.021 & 0.040 & 0.061 \\
& Ada & 0.042 & 0.065 & 0.120 & 0.023 & 0.038 & 0.062 \\
\hline
\end{tabular}

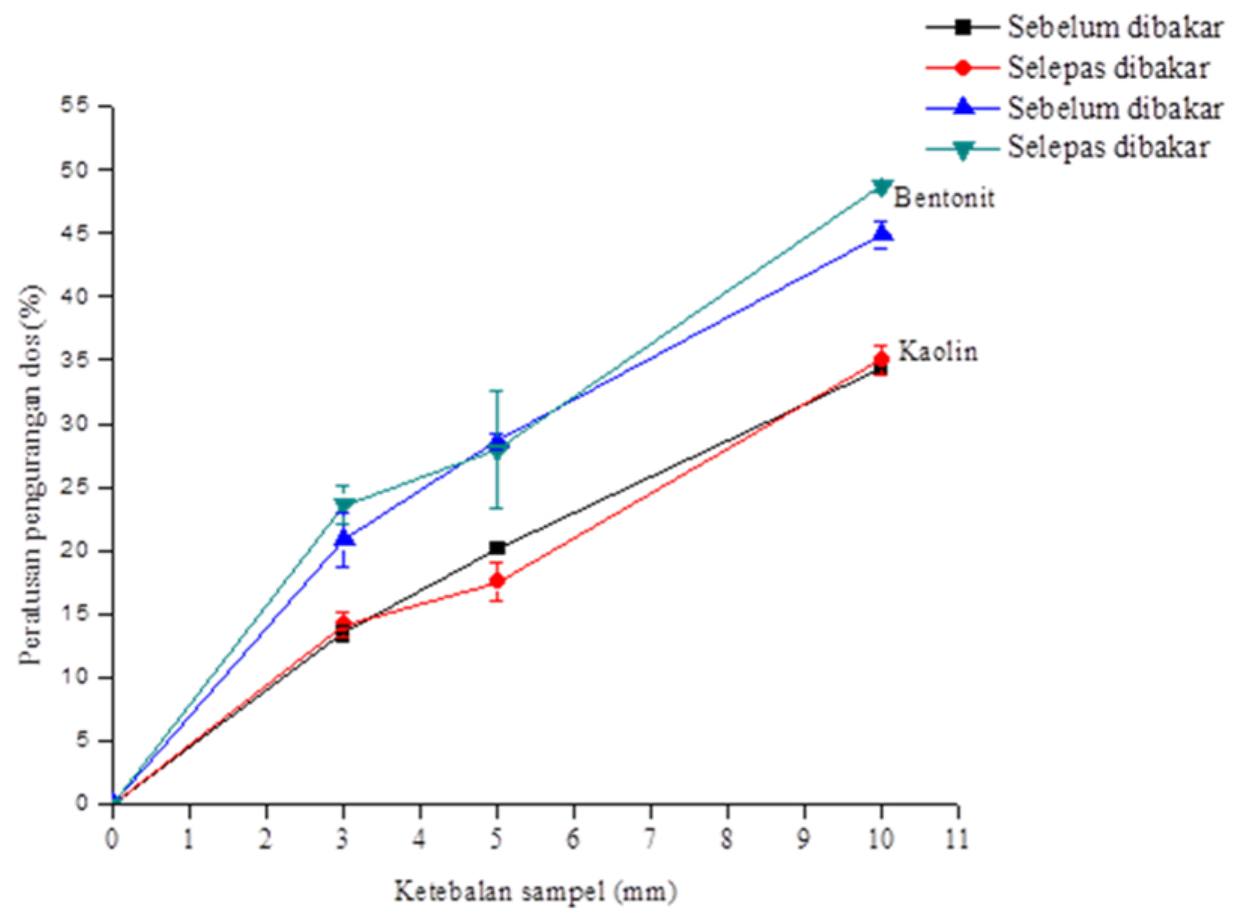

RAJAH 4. Peratusan pengurangan dos (\%) melawan ketebalan sampel bentonit dan kaolin (mm) bagi sumber sinaran gama 


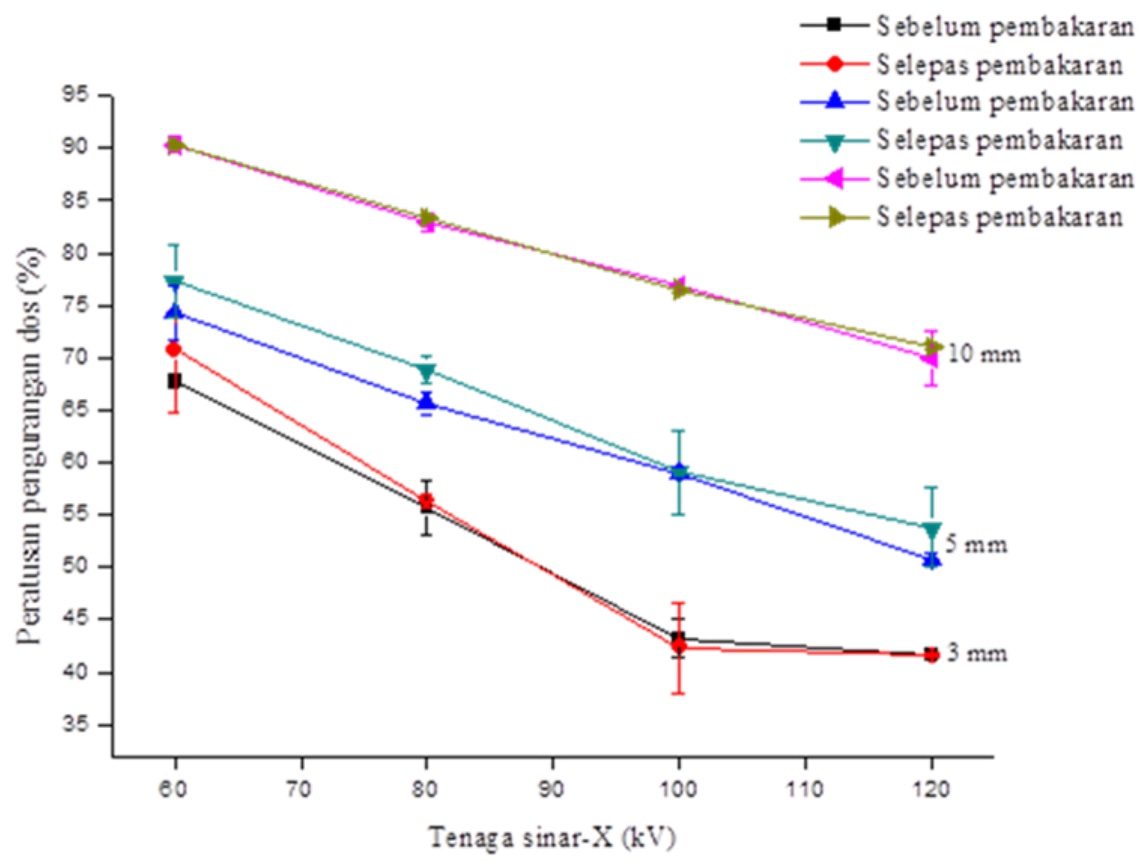

RAJAH 5. Peratusan pengurangan dos (\%) bentonit melawan tenaga sinar-X $(\mathrm{kV})$

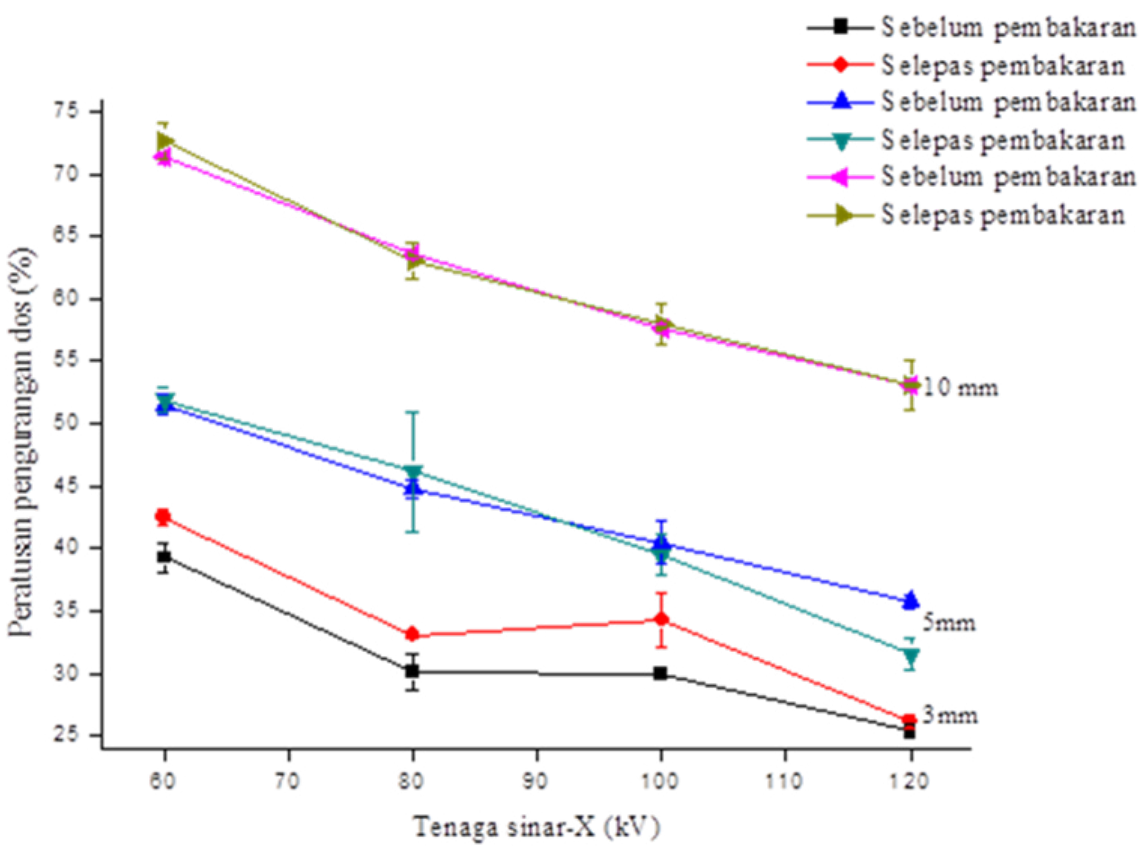

RAJAH 6. Peratusan pengurangan dos (\%) kaolin melawan tenaga sinar-X (kV)

kaolin memerlukan ketebalan sebanyak dua kali ganda lebih tinggi berbanding bentonit bagi menghalang sinar-X.

\section{PERATUSAN PENGURANGAN DOS BAGI SAMPEL BENTONIT DAN KAOLIN}

Rajah 4 menunjukkan keupayaan sampel tanah liat bentonit dan kaolin dalam menghalang sinaran gama (Am-241). Berdasarkan rajah tersebut, peratusan pengurangan dos bagi sampel bentonit adalah tinggi berbanding kaolin.
Semakin tinggi ketebalan sampel, semakin tinggi peratusan pengurangan dos. Pada ketebalan $10 \mathrm{~mm}$, peratus pengurangan dos bagi seramik bentonit, $\mathrm{B}(10)^{\mathrm{c}}$ adalah $49 \%$, iaitu $13 \%$ lebih tinggi berbanding seramik kaolin, $\mathrm{K}(10)^{\mathrm{c}}$.

Rajah 5 dan 6 menunjukkan keupayaan sampel bentonit dan kaolin dalam menghalang sinar-X pada tenaga keupayaan yang berbeza. Semakin tinggi tenaga sinar-X, semakin kurang peratusan pengurangan dos diperoleh. 
Peratusan pengurangan dos yang tertinggi adalah pada sampel bentonit yang berketebalan $10 \mathrm{~mm}$ selepas disinarkan dengan $60 \mathrm{kV}$ sinar-X iaitu sebanyak $90 \%$ berbanding $65-80 \%$ pada bentonit berketebalan 3 dan 5 $\mathrm{mm}$. Pada tenaga sinar-X yang sama, peratusan pengurangan sampel bentonit adalah $50 \%$ lebih tinggi berbanding sampel kaolin (iaitu hanya 70\% pengurangan direkodkan pada sampel kaolin). Kesimpulannya, peratusan pengurangan dos bagi sampel bentonit adalah tinggi berbanding sampel kaolin selari dengan keputusan yang diperoleh dalam ujian lengkung kalibrasi dan $\mu$.

\section{KESIMPULAN}

Secara keseluruhan, sampel tanah liat (bentonit dan kaolin) menunjukkan pengurangan dos sinar gama dan sinar-X, justeru, sesuai dijadikan sebagai perisai sinaran. Peratusan pengurangan adalah bergantung kepada ketebalan sampel tanah liat dan nilai tenaga yang disinarkan. Proses pembakaran pada suhu tinggi (sampel seramik) tidak menunjukkan perbezaan yang ketara antara sampel asal tanah liat. Namun, bagi menjadi bahan perisai sinaran, ketahanan mekanikal perlu dititikberatkan. Justeru, penambahan komposisi bahan-bahan lain boleh dipertimbangkan bagi menguatkan struktur fizikal dan mekanikal tanah liat kaolin dan bentonit.

\section{PENGHARGAAN}

Penulis merakamkan penghargaan kepada semua pihak yang terlibat, sokongan dana GUP-2017-085 daripada Universiti Kebangsaan Malaysia (UKM) dan geran FRGS/1/2019/STG02/UKM/02/6 daripada Kementerian Pendidikan Malaysia, seterusnya Jabatan Fizik Gunaan, Fakulti Sains dan Teknologi (FST), serta Pusat Pengurusan Penyelidikan dan Instrumentasi (CRIM) untuk kemudahan yang disediakan. Ucapan terima kasih juga ditujukan kepada Agensi Nuklear Malaysia atas bantuan penggunaan peralatan penyelidikan dan kepakaran.

\section{RUJUKAN}

Ekosse, G.I.E. \& Mulaba-Bafibiandi, A.F. 2008. Mineral thermochemistry of bentonite and kaolin related to their possible application in the ceramic industry. Journal of Applied Sciences 8(22): 4145-4151.

Erdem, M., Baykara, O., Doğru, M. \& Kuluöztürk, F. 2010. A novel shielding material prepared from solid waste containing lead for gamma ray. Radiation Physics and Chemistry 79(9): 917-922.

Folorunso, D.O., Olubambi, P. \& Borode, J.O. 2014. Characterization and qualitative analysis of some nigerian clay deposits for rafractory applications. IOSR Journal of Applied Chemistry 7(9): 40-47.

Górniak, K., Szydłak, T., Gaweł, A., Klimek, A., Tomczyk, A., Sulikowski, B., Olejniczak, Z., Motyka, J., Serwicka, E.M. \& Bahranowski, K. 2016. Commercial bentonite from the Kopernica deposit (Tertiary, Slovakia): A petrographic and mineralogical approach. Clay Minerals 51(1): 97-122.
Hopkins, D.N., Maqbool, M. \& Islam, M.S. 2012. Linear attenuation coefficient and buildup factor of MCP-96 alloy for dose accuracy, beam collimation, and radiation protection. Radiological Physics Technology 5(2): 229236.

Kementerian Kesihatan Malaysia. 2017. Manual Perlaksanaan Program Jaminan Kualiti (QAP) dalam Perkhidmatan Radiologi. Kementerian Kesihatan Malaysia.

Kłosek-Wawrzyn, E., Małolepszy, J. \& Murzyn, P. 2013. Sintering behavior of kaolin with calcite. Procedia Engineering 57: 572-582.

Mann, H.S., Brar, G.S. \& Mudahar, G.S. 2016. Gamma-ray shielding effectiveness of novel light-weight clay-flyash bricks. Radiation Physics and Chemistry 127: 97-101.

Naswir, M., Arita, S., Marsi. \& Salni. 2013. Characterization of bentonite by XRD and SEM-EDS and use to increase $\mathrm{pH}$ and color removal, $\mathrm{Fe}$ and organic substances in peat water. Journal of Clean Energy Technologies 1(4): 313317.

Olukotun, S.F., Gbenu, S.T., Ibitoye, F.I., Oladejo, O.F., Shittu, H.O., Fasasi, M.K. \& Balogun, F.A. 2018. Investigation of gamma radiation shielding capability of two clay materials. Nuclear Engineering and Technology 50(6): 957-962.

Ripin, A., Mohamed, F., Idris, M.I. \& Suhaimin, N.S. 2019. Kesan integriti pemerisaian sinaran seramik mullite-barite (MBC) terhadap kejadian kebakaran. Sains Malaysiana 48(2): 443-449.

Ripin, A., Mohamed, F., Choo, T.F., Yusof, M.R., Hashim, S. \& Ghoshal, S.K. 2018. X-ray shielding behaviour of kaolin derived mullite-barites ceramic. Radiation Physics and Chemistry 144: 63-68.

Saeed, K.A.H., Khairul, H., Kassim, A. \& Yunus, N.Z.M. 2013. Characterization of hydrated lime-stabilized brown kaolin clay. International Journal of Engineering Research \& Technology (IJERT) 2(11): 3722-3726.

Singh, N., Singh, K.J., Singh, K. \& Singh, H. 2004. Comparative study of lead borate and bismuth lead borate glass systems as gamma-radiation shielding materials. Nuclear Instruments and Methods in Physics Research Section B: Beam Interactions with Materials and Atoms 225(3): 305309.

Tilki, T., Şekerci, M., Çapali, V., Kaplan, A. \& Yavuz, M. 2017. Comparison of bentonite and Sn doped bentonite samples under the effects of proton and electron irradiation. Journal of Interaction of Radiation with Solids 3: 111-113.

Toshifumi, S., Lynne, E., Simerjeet, G. \& Butcher, T. 2010. Carbonation of clay minerals exposed to $\mathrm{scCO}_{2} /$ Water at $200^{\circ}$ and $250^{\circ}$ C. U.S. Department of Energy Office of Scientific and Technical Information. doi:10.2172/1033188.

Yusuf Abdullah, Mohd Reusmaazran Yusof, Azali Muhamad, Samsu, Z. \& Abdullah, N.E. 2010. Cement-boron carbide concrete as radiation shielding. Journal of Nuclear and Related Technologies 7(2): 6.

Nur Fatin Nabilah Zuhairi, Norsyahidah Mohd Hidzir*, Mohd Idzat Idris \& Nur Ain Mohd Radzali

Pusat Penyelidikan Teknologi Nuklear

Fakulti Sains dan Teknologi

Universiti Kebangsaan Malaysia

43600 UKM Bangi, Selangor Darul Ehsan

Malaysia 
Nur Fatin Nabilah Zuhairi, Norsyahidah Mohd Hidzir, Mohd Idzat Idris \& Nur Ain Mohd Radzali

Jabatan Fizik Gunaan

Fakulti Sains dan Teknologi

Universiti Kebangsaan Malaysia

43600 UKM Bangi, Selangor Darul Ehsan

Malaysia

\section{Azuhar Ripin}

Kumpulan Fizik Perubatan

Agensi Nuklear Malaysia

43000 Kajang, Selangor Darul Ehsan

Malaysia
*Pengarang untuk surat-menyurat; email: syahidah@ukm.edu. my

Diserahkan: 7 Oktober 2019

Diterima: 3 Disember 2019 
